\title{
MIDDLE PERMIAN TELODIAGENETIC PROCESSES IN NEOPROTEROZOIC SEQUENCES, TANDILIA SYSTEM, ARGENTINA
}

\author{
PATRICIA EUGENIA ZALBA, ${ }^{1}$ MARCELO MANASSERO, ${ }^{2}$ EMMANUEL LAVERRET, ${ }^{3}$ DANIEL BEAUFORT, ${ }^{4}$ ALAIN MEUNIER, ${ }^{4}$ \\ MARTÍN MOROSI, ${ }^{1}$ AND LAURA SEGOVIA ${ }^{1}$ \\ ${ }^{1}$ Comisión de Investigaciones Cientificas Provincia de Buenos Aires-CETMIC-Facultad de Ciencias Naturales y Museo de La Plata, Camino Centenario y 506, \\ Manuel Benito Gonnet 1897, Argentina \\ ${ }^{2}$ CONICET-Centro de Investigaciones Geológicas, Facultad de Ciencias Naturales y Museo de La Plata, Calle 1 \#644, La Plata 1900, Argentina \\ ${ }^{3} \mathrm{CV}$-associés, 225 Rue Gaston Doumergue, 31170 Tournefeuille, France \\ ${ }^{4}$ Université de Poitiers-HYDRASA, 40 Avenue Recteur Pineau, Poitiers 86022, France \\ e-mail: pezalba@cetmic.unlp.edu.ar
}

\begin{abstract}
In the Tandilia Basin, Buenos Aires Province, Argentina, we study the genesis of mud beds and pipes in the Loma Negra Formation (limestones), Sierras Bayas area, together with the emplacement of alunite and aluminum phosphate sulfate (APS) minerals in the Las Aguilas Formation, Barker area. All these features are related to basin inversion, uplift, erosion, and injection or expulsion, or infiltration of fluids and oxidation reactions in the exhumed rocks during a telodiagenetic stage. On the basis of K-Ar dating of alunite in the Las Aguilas Formation (claystones) giving an age of $254 \pm 7 \mathrm{Ma}$ (middle Permian), these processes are considered to be linked to a major geological event which affected these Neoproterozoic lithostratigraphic units: the folding of the Ventania System, located $150 \mathrm{~km}$ to the SW of the study area.
\end{abstract}

\section{INTRODUCTION}

It is well known that diagenesis consists of a dynamic suite of processes linked to the burial history of the sedimentary basin, and that the conditions which favored different diagenetic reactions were recorded in both the diagenetic fabric and mineralogy of the resulting rocks (Worden and Burley 2003). However, use of diagenetic features to decipher the burial history of ancient basins implies the capacity to distinguish the products of the diagenetic reactions which characterized the different diagenetic regimes at various points in the history of the basin. It is crucial to distinguish signatures of uplift-related processes (telodiagenesis) which occurred in the sedimentary rocks that have been exposed to the influx of meteoric waters. Signatures of telodiagenesis can help to reconstruct the basin evolution in ancient continents.

On the basis of field observations, stratigraphic profiles, and petrographic, mineralogical, and isotopic analyses we studied important structural features and mineralogical changes experienced by the sediments in two different areas: Sierras Bayas and Barker (Fig. 1).

In the Sierras Bayas area, the presence of mud beds within limestones connected to vertical mud pipes, the evidence of fluidization of fine sediments, the development of dissolution fronts, and disruption and faulting of the host rocks are studied and linked to transformation of mineral phases.

In the Barker area, $90 \mathrm{~km}$ SE from Sierras Bayas, important mineralogical changes within claystone deposits led to a set of secondary reactions with the neoformation of mineral phases.

The goal of this study is the interpretation and timing of several structural and late diagenetic features which affected Neoproterozoic lithostratigraphic units in these two sites, to explain the mechanisms involved and to develop a new stage in the tectonosedimentary evolution of the Tandilia System relating these diagenetic signatures to the geologic history of the Ventania folded system, located $150 \mathrm{~km} \mathrm{SW}$ from the Tandilia System.

\section{GEOLOGIC SETTING}

Tandilia (Fig. 1) is a discontinuous NW-SE mountain range which extends $300 \mathrm{~km}$ in the Province of Buenos Aires, running between $36^{\circ} 30^{\prime}$ to $38^{\circ} 5^{\prime} \mathrm{S}$ latitude and $58^{\circ}$ to $62^{\circ} \mathrm{W}$ longitude. This range comprises Paleoproterozoic to Neoproterozoic crystalline basement rocks (2200-600 Ma; Cazenueve 1967; Stipanicic and Linares 1969; Halpern and Linares 1970; de Almeida 1971; Varela et al. 1988) covered by Neoproterozoic to lower Ordovician sedimentary sequences dated by trace fossils or stromatolite structures (Borrello 1966; Amos et al. 1972; Aceñolaza 1979; Dalla Salda and Iñíguez 1979; Del Valle 1987) and by Rb-Sr and $\mathrm{K}-\mathrm{Ar}$ geochronological data (Rapela et al 1974; Bonhomme and Cingolani 1980; Cingolani and Bonhomme 1982; Cingolani 1988).

Several sedimentary cycles divided by regionally extensive unconformities were created by sea-level changes (Iñíguez et al. 1989; del Valle 1990; Poiré 1993; Andreis et al. 1996; Poiré and Spalletti 2005). These cycles are consistent with Neoproterozoic lithostratigraphic units (Villa Mónica, Cerro Largo, Olavarría, Las Aguilas, Loma Negra, and Cerro Negro) and with the Ordovician Balcarce Formation, which are displayed in Figure 2, along with their ages and lithologies. The Las Aguilas Formation has been correlated with the Cerro Negro Formation (Iñíguez et al. 1989) and, recently, with the Olavarría Formation (Poiré and Spalletti 2005)

The Neoproterozoic and Ordovician clay deposits (see Fig. 2) are sedimentary and show different grain-size distributions (Iñíguez 1965; Zalba 1979; Dalla Salda and Iñíguez 1979; Iñíguez et al. 1989; Zalba 


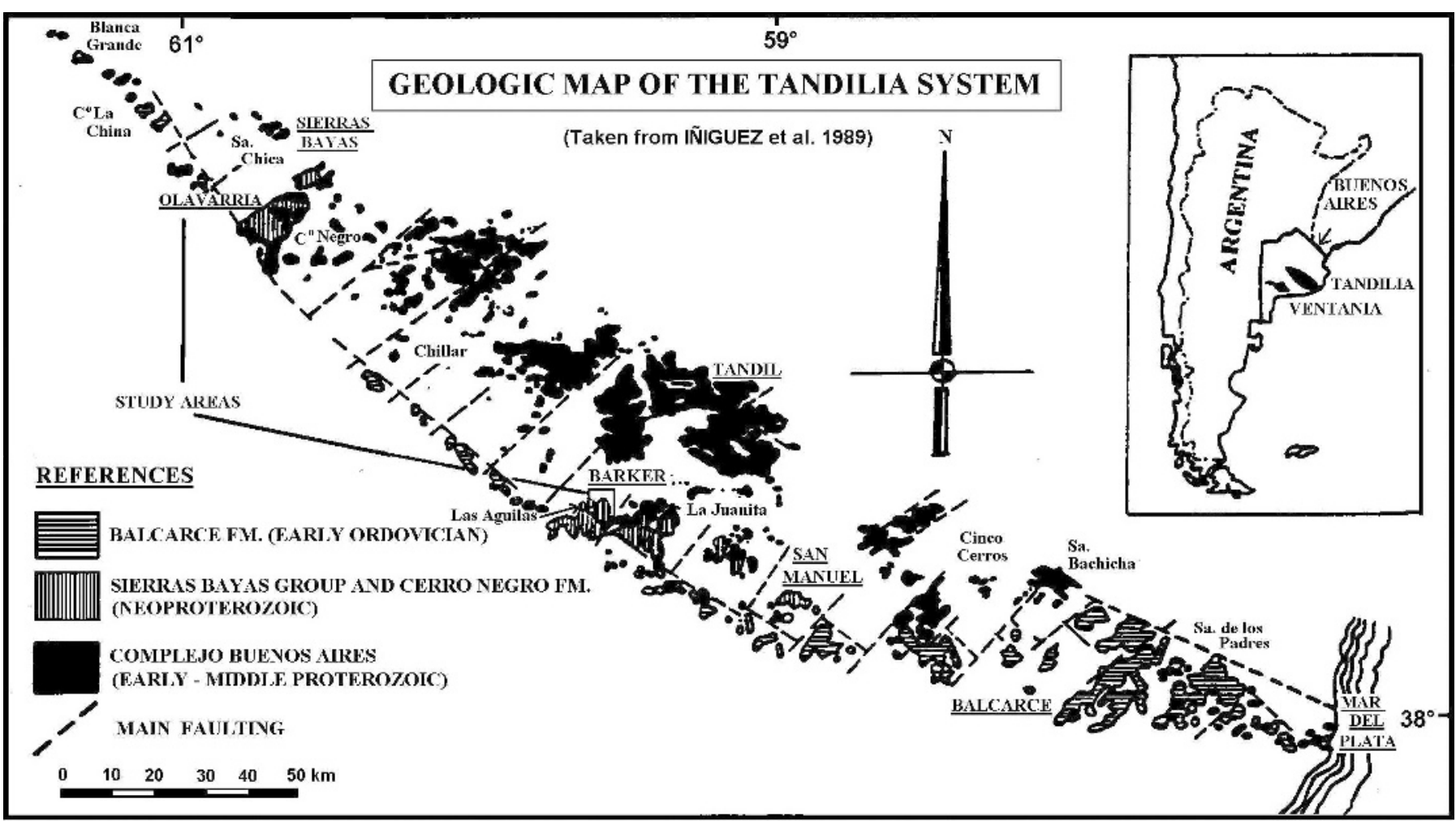

Fig. 1.-Geologic map of the Tandilia System, Buenos Aires, Argentina (taken from Iñíguez et al. 1989). Study areas: Sierras Bayas and Barker (Cuchilla de Las Aguilas).

1982; Zalba et al. 1988; Andreis et al 1996; Poiré 1993; Poiré and Spalletti 2005).

Mineralogically, from optical microscopy, SEM evidence, and X-ray powder diffraction and chemical and thermal analyses, the sedimentary clays are mechanical admixtures of several phyllosilicates, quartz, and very scarce feldspars. Morphologically, the phyllosilicates may occur as irregular plates of ill-defined forms (illite), as individual, rather hexagonal plates (kaolinite), and as prismatic, large plates with straight edges

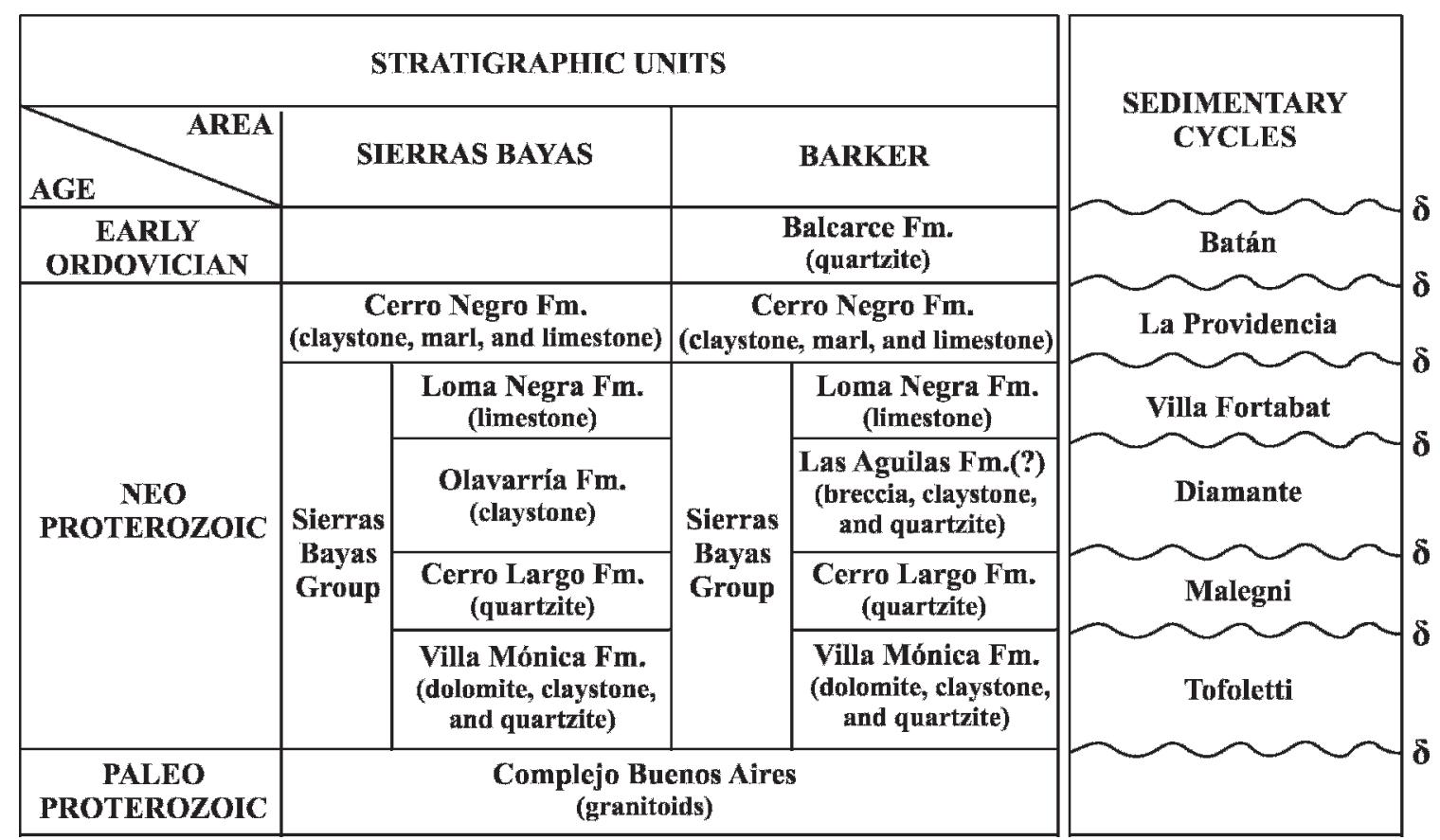

Fig. 2.- Stratigraphic units and sedimentary cycles of the Tandilia System for the Sierras Bayas and the integrated Barker-Cuchilla de Las Aguilas areas. $\delta$ discordance. Modified from Iñíguez et al. (1989), Andreis et al. (1996), and Poiré and Spalletti (2005). 
(pyrophyllite). Texturally, euhedral to subhedral individual flakes show different compaction features. Kaolinitic clays deposited in the flocculated state, and settled out in face-to-face relationship, which Murray (1976) reported as having been deposited as flocs.

The origin of pyrophyllite contained in the sediments of the Las Aguilas Formation (Barker area) is still debated. It has been interpreted as hydrothermal alteration of the sediments (cf. Di Paola and Marchese 1974; Dristas and Frisicale 1996, 2003; Frisicale and Dristas 2000) or as detrital minerals provided by the erosion of metamorphic basement rocks (Zalba 1979, 1982; Zalba et al. 1988; Iñíguez et al. 1989).

Superimposed diagenetic processes are responsible for the formation of diverse mineral species in the clay deposits (Zalba 1982; Zalba et al. 1988). According to Zalba (1982) the main diagenetic associations in the various lithostratigraphic units are: (1) stacks of hexagonal plates of kaolinite coexisting with elongated crystals of diaspore, tiny pseudocubes of alunite, tubes of halloysite, and hematite pseudomorphs after pyrite (Las Aguilas Formation), (2) illitic-chloritic clays with ordered I/S (illite/ smectite) oriented perpendicular to grain surface, showing a characteristic box-work texture coexisting with pseudocubes of alunite, as well as random chlorite-smectite mixed-layer minerals (Cerro Negro Formation), and (3) ordered I/S and hematite after authigenic pyrite (Olavarría Formation). Ordered I/S (with $<15 \%$ smectite) is a common mineral in all the Neoproterozoic units, but it is a minor component in the Ordovician clay deposits of the Balcarce Formation (Zalba and Andreis 2001).

$\mathrm{Rb} / \mathrm{Sr}$ and $\mathrm{K} / \mathrm{Ar}$ radiometric data obtained from illitic claystones of the Sierras Bayas Group by Bonhomme and Cingolani (1978) showed that diagenetic processes occurred during the late Precambrian for these deposits. From $\mathrm{K} / \mathrm{Ar}$ and $\mathrm{Rb} / \mathrm{Sr}$ geochronological dating of illitic (illite and I/S with $<15 \%$ smectite) clays of the Cerro Negro Formation, Cingolani and Bonhomme (1982) obtained an average age of $723 \pm 32$ Ma for the early diagenesis of this unit, very close to the depositional age. On the other hand, there are no available data on the age of diagenetic processes in the Ordovician Balcarce Formation.

The sedimentary sequences of Tandilia have probably not exceeded 2 $3 \mathrm{~km}$ of burial. This statement is based on the comparatively simple authigenic mineralogy of these successions (cf. Iñíguez and Zalba 1974; Iñíguez et al. 1989; Zalba 1982), also revealed on several world examples of onshore basin-margin sequences (Hebridean Basins, Morton 1987; Yorkshire Basin, Hemingway and Riddler 1982; Dorset Basin, Scotchman 1991a and 1991b), which, according to these authors, experienced $2.5 \mathrm{~km}$ of burial. Furthermore, the abundance of compaction features like straight-line and suture boundaries and especially the presence of triple junctions in sandstones (Ahmad and Bhat 2005) observed in the quartzites of the Sierras Bayas Group and of the Balcarce Formation (Iñiguez et al. 1996) support this assumption.

Deformational structures have been described in the claystones of the Olavarría Formation in the Sierras Bayas area, Tandilia System, by previous authors. Massabié et al. (1992) documented mud diapirs and attributed them to tectonic shearing of presumed Devonian to PermianTriassic age. Sellés Martinez (1994) also described clay diapirs and hydraulic breccias in the Loma Negra Formation in the same area and suggested that these structures could be related to the diagenetic history of the Tandilia System. Also, Andreis and Zalba (1989) maintained that folding and other structural features found in the Tandilia System (Las Aguilas Formation) give evidence for compressive movements from the SW and associated them with the deformation of the Ventania System (located $150 \mathrm{~km} \mathrm{SW}$ from the Tandilia System) during Gondwana times.

The nearby and most probable deformational phase that may have caused injection structures and induced important mineralogical changes is the folding that affected the Ventania System. A well documented age for this event is based on $\mathrm{Rb}-\mathrm{Sr}$ and $\mathrm{K}-\mathrm{Ar}$ geochronological data, mostly from white mica and illite of the sediments (Gosen and Buggish 1989).
These authors suggested that the deformation must have occurred during middle to Late Permian. Other workers (Varela et al. 1985) have placed a unique deformational event for the Ventania System in the middle Permian on the basis of $\mathrm{K}-\mathrm{Ar}$ dating on clays of the Mascota Formation. These authors concluded that the most probable age of the main folding of Ventania was between the latest part of the Early Permian and the Permian-Triassic boundary.

By means of seismic and drilling data, Lesta and Sylwan (2005) found more than $10,000 \mathrm{~m}$ of sedimentary cover in the Claromecó Basin, located between the Tandilia and Ventania systems. It is a basin originally developed as a rift, which then evolved into an intracratonic basin, and later as a back-arc foreland basin. Four sedimentary cycles, bounded at their bases by unconformities, have been identified and correlated with the exposures at Ventania and Tandilia. These authors concluded that a Permian-Triassic compressional event uplifted and exhumed a thick column of sedimentary cover which has been totally eroded. There is no record of Mesozoic sedimentation, inasmuch as the Cenozoic overlies, unconformably, the Paleozoic with a thin sedimentary cover (less than $300 \mathrm{~m}$ ).

Furthermore, Lesta and Sylwan (2005) demonstrated that the north margin of the Claromecó Basin is controlled by the Tandilia System, with the thinning up of all of the sedimentary units in that direction, and this fact allowed the authors to assume that the Tandilia System represents an ancient elevation (horst) which must have conformed at some moment during the early Paleozoic, probably after the Ordovician and before the Devonian.

\section{METHODS AND ANALYTICAL TECHNIQUES}

Petrographic analyses were performed on an Olympus BX60 optical microscope. X-ray diffraction analyses were carried out on a Philips Xpert Pro device equipped with an Xcelerator detector, at $40 \mathrm{kV}$ and $40 \mathrm{~mA}$, with $\mathrm{Cu} \mathrm{K} \alpha$ radiation and a Ni filter. Clay minerals (size fraction $<2 \mu \mathrm{m}$ ) were analyzed on oriented preparations and randomly oriented powders for routine analysis (air dried, glycolated overnight, and heated for $2 \mathrm{hrs}$. at $550^{\circ} \mathrm{C}$ ). Interstratified clay minerals were identified using the Newmod program (Reynolds 1985). Textures, porosity, and mineralogical and chemical composition of the sediments were examined using a Jeol JSM 5800 scanning electron microscope equipped with an Oxford energy-dispersive spectrometer (EDS).

$\mathrm{K}-\mathrm{Ar}$ isotopic analyses were performed at the Centre de Géochimie de la Surface of the University of Strasbourg using a procedure similar to that developed by Bonhomme et al. (1975). Potassium was measured by atomic absorption with an overall accuracy of $\pm 1.5 \%$. Ar was analyzed in samples pre-heated under high vacuum at $100^{\circ} \mathrm{C}$ for at least 12 hours to reduce the amount of atmospheric Ar adsorbed on the mineral surfaces during sample preparation and handling. Ar isotopic results were controlled by repetitive analysis of the international GL-O standard that averaged $24.38 \pm 0.12 \times 10^{-6} \mathrm{~cm}^{3} / \mathrm{g}$ STP $(2 \sigma)$ of radiogenic Ar for two determinations. The blank of the extraction line and the mass spectrometer were also periodically controlled, the amount of residual ${ }^{40} \mathrm{Ar}$ being systematically below $1 \times 10^{-7} \mathrm{~cm}^{3} / \mathrm{g}$ STP. The usual decay constants were used for age calculations (Steiger and Jäger 1977) and the overall error of the $\mathrm{K}-\mathrm{Ar}$ age determinations was evaluated to be better than $2 \%$.

\section{RESULTS}

\section{Mud Beds and Pipes in the Sierras Bayas Area}

A subhorizontal, north-south-oriented mud bed is exposed along $300 \mathrm{~m}$ at the "La Pampita" quarry (14.5 km SW of Olavarría City, Fig. 1) within a 15-m-thick limestone outcrop of the Loma Negra Formation, Sierras Bayas area (Fig. 3). The mud bed, with concave-up 


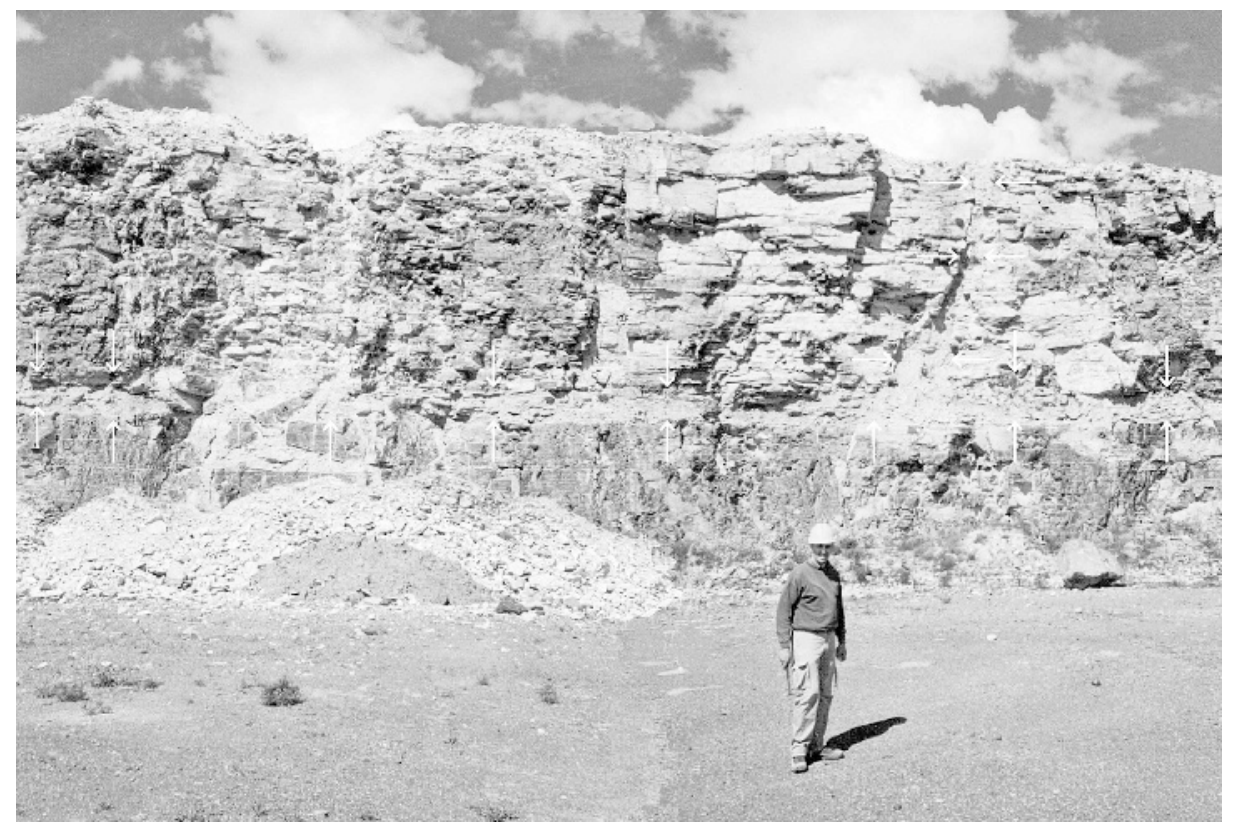

Fig. 3.- General view of a north-south limestone front at La Pampita quarry, near Olavarría, Sierras Bayas area. The vertical arrows indicate a subhorizontal mud bed within the limestones of the Loma Negra Formation. The horizontal arrows indicate a mud pipe, connected with the mud bed. planes, shows a nearly consistent thickness of $1.50 \mathrm{~m}$, with localized gaps of about $0.20 \mathrm{~m}$ wide (Fig. 4A, B), and it overlies a lenticular polymictic orthoconglomerate of $0.05 \mathrm{~m}$ to $0.20 \mathrm{~m}$ thick. Both the lower and the upper contacts between the mud bed and the limestone are parallel to the local bedding. Dissolution features of the limestone are obvious at the contact with the clay material. The structures of the limestones vary according to their location compared to the mud bed. Underlying limestones are massive and rather undisrupted, whereas overlying ones are dislocated and displaced along vertical open fractures. Several small grabens have been observed in the overlying limestones, with downwardcollapsing blocks (up to $3 \mathrm{~m}$ long) leading to thinning of the mud bed (Fig. 4B). A NE-SW fault system has been observed in the quarry.

Clasts and rock fragments (from millimeters to $5 \mathrm{~cm}$ long) of the polymictic orthoconglomerate are irregular in shape, ranging from subangular to well rounded and showing a predominantly random orientation. Nevertheless, some large, elongate fragments show a preferred N-S alignment of their longest axis. The matrix is composed of very scarce, fine to coarse sand grains cemented by calcite.

Several vertical mud pipes have been observed in the La Pampita quarry (Fig. 4A). All of them are connected to the aforementioned mud bed and intersect the bedding of the overlying limestone over distances which vary from $2 \mathrm{~m}$ up to the present erosion surface $(7 \mathrm{~m})$. It should be noted that downward mud pipes have never been observed in the underlying limestones.

Small blocks of limestone were found in the clay pipes. The contacts between the clay pipes and the host rock (limestone) exhibit the following features: (1) marked deformation of disrupted limestone strata with a similar subvertical reorientation on both sides of the clay pipe (Fig. 4A), and (2) consequent dissolution of the disrupted limestone strata. At least six other clay pipes of the same style (Fig. 4C) are exposed along the contact between the Loma Negra Formation and the underlying clay deposits of the Olavarría Formation, $200 \mathrm{~m} \mathrm{NE}$ from the first limestone front described, and also in the Cementos Avellaneda quarry, $3.2 \mathrm{~km} \mathrm{NE}$ from the La Pampita quarry. All of these other mud pipes are directly connected with the Olavarría Formation. The erosional unconformity between the Olavarría and the Loma Negra formations (Andreis et al. 1996) has been partially obliterated by the development of a continuous dissolution front of the overlying limestone (Fig. 4C). Several features related to compressive effects and folding of the strata have been observed in the underlying Olavarría Formation.

The polymictic orthoconglomerate fabric exhibits chemical-alteration features: corroded quartz grains with dissolution texture, replacement of quartz and feldspars by calcite, dissolution of feldspar crystals, and intergranular stylolites parallel to bedding. The altered debris is cemented by calcite, with sparitic, spherulitic, acicular, granular, or poikilotopic textures. Grain-breaking and displacement of quartz, microcline, quartzite, and clay fragments are here attributed to fluid pressure producing a floating texture (Fig. 5A ). Petrographic studies show that the sparite records up to three successive growing pulses, displacing and replacing the matrix and also filling cracks and fissures (Fig. 5A). The contact between the conglomerate and the underlying limestone shows dissolution-precipitation features leading to chalcedony and calcite crystallization in voids. Late mineralization events comprise hematite precipitation in cement void space (Fig. 5B, D).

The stages of the development of cements in the conglomerate and in the contact between the limestone and the conglomerate can be summarized as follows:

1. Development of microsparite cement filling all the pore space available (first pulse).

2. Recrystallization of intergranular microsparite into macrosparite (second pulse) arranged in a poikilotopic texture.

3. Fracturing of the framework and the cements and filling of the cracks with a third pulse of sparite cement.

4. Opal precipitation in voids and recrystallization to chalcedony usually restricted to the cement contacts and also dissolving macrosparite and microsparite cements.

5. Crystallization of hematite around clasts as well as in cement voids.

The overlying mud bed consists of clasts and small blocks (rock fragments ranging from millimeters to $3 \mathrm{~cm}$ ) supported by a clay matrix. Rounded quartz (monocrystalline) and angular feldspar (microcline, orthoclase, and plagioclase) crystals predominate over lithic grains (elongate clay fragments, rounded granite-cataclasite, orthoquartzite, chert, and polycrystalline quartz). The sediments are poorly sorted and texturally immature, with features of grain fragmentation (Fig. 5D). The light brown clay matrix shows slickensides, and preferred orientation of 
clay minerals can be seen in the matrix which fills space between the disrupted grains. Tangential clay and hematite coating is present around grains and as fracture-filling material. Aggregates of coarse-grained calcite (up to $0.50 \mathrm{~m}$ long) and rounded to elongated barite clasts ( 0.5 to $2 \mathrm{~mm}$ long) are found. The sediments are poorly lithified (no cementation features) and without any stratification or grading.

$\mathrm{X}$-ray diffraction patterns from clay material from the subhorizontal mud bed at La Pampita quarry (Fig. 6A) indicates that random I/S (with $70 \%$ smectite) is the predominant clay-mineral component. A similar type of random I/S (up to $90 \%$ smectite) has also been identified in the mud pipes connected with the Olavarría Formation (Fig. 6B) related to the dissolution front developed at the contact between the Olavarría Formation and the Loma Negra Formation. At the base of the Olavarría Formation clay minerals consist of illite and ordered I/S (with $<15 \%$ smectite, Fig. 6C) similar to those found regionally in this unit (Zalba et al. 1996).

\section{Alunite and Aluminium Phosphate Sulfate (APS Minerals) in Claystone Deposits of the Barker Area}

The Las Aguilas Formation (Fig. 7) outcrops in the Cuchilla de Las Aguilas and the Sierra La Juanita (Barker area) areas and was divided, from base to top, into three lithofacies (Zalba et al. 1988): breccias (Lower Lithofacies), claystones and mudstones (Middle Lithofacies) and alternating claystone, siltstone, and sandstone sediments (Upper Lithofacies). The quartzitic sediments overlying the Upper Lithofacies were originally considered as the base of the Balcarce Formation (Zalba et al. 1982).

Lenses of alunite $\left(\mathrm{KAl}_{3}\left(\mathrm{SO}_{4}\right)_{2}(\mathrm{OH})_{6}\right)(0.05$ to about $0.25 \mathrm{~m}$ thick and hundreds of meters in lateral extent) occurs along sedimentary discontinuities, either at the contact between the Middle Lithofacies and the interbedded claystone-siltstone-sandstone deposits of the Upper Lithofacies or, in lesser amounts, intercalated in the first $0.60 \mathrm{~m}$ of the Upper Lithofacies (Fig. 8A). In the contact between the Middle and the Upper Lithofacies, alunite occurs within or at the base of, bleached clay levels (light gray to white colored), 1 to 2 meters thick. Petrographic observations indicate that the alunite crystals forming the lenses present a columnar habit, typical of crystallization at the walls of open spaces and of a continuous growth, according to the principle of the geometrical selection generally invoked for the occurrence of drusy crystals (Grigor'ev 1965). The Middle Lithofacies is composed of massive or laminated claystones with minor interbedded sandstones and siltstones. These sediments are red colored at the base, brownish-red at the middle section, and greenish-gray to yellowish-gray at the top. Several lenses of silica nodules (now quartz) were observed in the upper part of the bleached clays containing the alunite deposits of the Upper Lithofacies. (Fig. 8B).

X-ray diffraction patterns of the clay material forming the above mentioned sedimentary layers with different colors indicate significant mineralogical changes. Major amounts of kaolinite and variable proportions of pyrophyllite are present, although the latter decreases upwards. Brownish-red and yellowish-gray clay-rich sediments contain illite and ordered I/S (with $<15 \%$ smectite), which decrease upwards with the appearance of alunite. Alunite is associated with diaspore, halloysite, and goethite. Variable quartz with overgrowths and very scarce feldspars are present.

The pyrophyllite, quartz, feldspars, and part of the kaolinite are considered to be of detrital origin and derived from the weathering, transport, and deposition of previously hydrothermalized crystalline basement rocks (gneisses) cropping out in the San Manuel area $(60 \mathrm{~km} \mathrm{E}$ from the Cuchilla de Las Aguilas) as stated by Zalba (1982), Zalba et al. (1988), and Zalba and Andreis (1998). Alunite, and part of the kaolinite, diaspore, halloysite, and goethite, were previously considered to be diagenetic mineral phases (Zalba 1982; Zalba et al. 1982; Zalba et al.
1988; Iñíguez et al. 1989). The basal reddish-clay sediments contain a high concentration of hematite, and numerous cubic pseudomorphous of hematite after pyrite have been recognized in the greenish-gray to yellowish-gray-clay levels (Fig. 8C). Alunite samples analyzed here correspond to the top of the Middle Lithofacies.

Massive alunite was identified by XRD and by SEM at the top of the Middle Lithofacies of the Las Aguilas Formation. It occurs as pseudocubic crystals (Fig. 9) associated with kaolinite, halloysite, and also diaspore and goethite (Zalba 1982; Zalba et al. 1988).

SEM and microprobe analyses performed on uncovered polished sections containing massive alunite allowed us to identify disseminated crystals of aluminum phosphate sulfate (APS) in the clay matrix (Fig. 10) whose microprobe analyses in percentages $\left(\mathrm{Al}_{2} \mathrm{O}_{3}, 30.57 \pm 0.59 ; \mathrm{P}_{2} \mathrm{O}_{5}\right.$, 22. $58 \pm 0.26 ; \mathrm{SO}_{3}, 5.89 \pm 0.17 ; \mathrm{SrO}, 8.33 \pm 0.62 ; \mathrm{CaO}, 1.23 \pm 0.06$ $\left.\mathrm{Ce}_{2} \mathrm{O}_{3}, 14.86 \pm 0.51\right)$ fall in the compositional field of a solid solution between svanbergite $\left(\mathrm{SrAl}_{3}\left(\mathrm{PO}_{4}, \mathrm{SO}_{4}\right)(\mathrm{OH})_{6}\right)$ and Ce-florencite $\left(\mathrm{CeAl}_{3}(-\right.$ $\left.\mathrm{PO}_{4}\right)_{2}(\mathrm{OH})_{6}$ ), two APS minerals of the beudantite and the crandallite groups, respectively (Gaboreau et al. 2005).

SEM images obtained in backscattering mode indicate that alunite has preferentially crystallized in the porous parts of the clay sediments (Fig. 11).

\section{K-Ar Isotopic Analyses of Alunite}

$\mathrm{K}-\mathrm{Ar}$ dating was carried out on three selected alunite samples (Table 1). The purity of the samples was checked by XRD, which indicates that alunite is mainly mixed with halloysite and/or kaolinite, two clay minerals which do not contain potassium.

The $\mathrm{K}-\mathrm{Ar}$ results were plotted on a ${ }^{40} \mathrm{Ar} /{ }^{36} \mathrm{Ar}$ vs. ${ }^{40} \mathrm{~K} /{ }^{36} \mathrm{Ar}$ isochron diagram (Fig. 12). The advantage of using the isochron technique is that the $\mathrm{K}-\mathrm{Ar}$ age calculation for a set of data points fitting a line and the determination of the corresponding initial ${ }^{40} \mathrm{Ar} /{ }^{36} \mathrm{Ar}$ of the representative samples is made without any assumption. The errors on the slope and intercept depend only on the fitting of the data. In the present case, the regressions were obtained by a Yorkfit regression using ISOPLOT (Ludwig 1991).

The $\mathrm{K}-\mathrm{Ar}$ data for the three samples define a line on an isochron diagram (Fig. 12) with a slope providing a K-Ar date of $254 \pm 7$ Ma with an intercept at 298.9, which is identical within analytical uncertainty to the measured atmospheric ${ }^{40} \mathrm{Ar} /{ }^{36} \mathrm{Ar}$ ratio of 300.7 . The mean squared weighted deviation (MSWD) is satisfying at 0.44 . The mean $\mathrm{K}-\mathrm{Ar}$ apparent ages of the same size fractions, based on the individual $\mathrm{K}-\mathrm{Ar}$ values, is $262 \pm 19 \mathrm{Ma}$, which is the same as the intercept age.

\section{DISCUSSION}

\section{Origin and Mechanisms of Formation of Mud Beds and Pipes}

The orthoconglomerate and the mud bed and pipes contain rock fragments from:

- Crystalline basement: orthoclase, microcline, polycrystalline quartz, and granite-cataclasite grains

- Cerro Largo Formation: orthoquartzite fragments

- Olavarría Formation: clays and barite fragments

- Loma Negra Formation: chert and limestone fragments

Both the mineralogical and the textural characteristics of the clay material observed within the poorly lithified mud bed and pipes intersecting the limestones of the Loma Negra Formation are consistent with the features of mud injection, which can occur in response to penetration of overpressured, fluidized muds along previously developed faults and fractures and/or sedimentary discontinuities within the limestones. The regular thickness of the mud infilling, the dissolution of the host limestone, and the precipitation of secondary minerals in open 

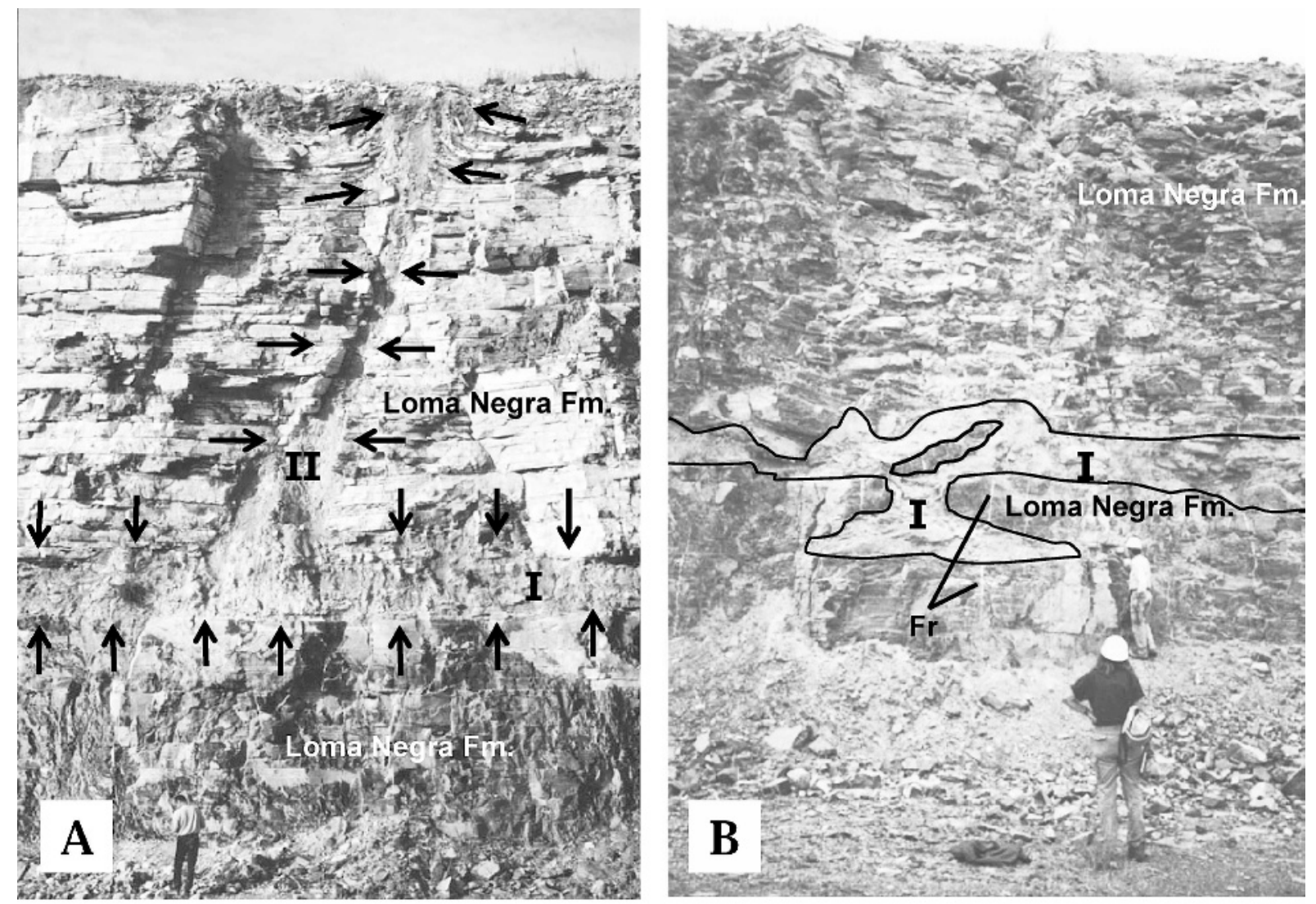

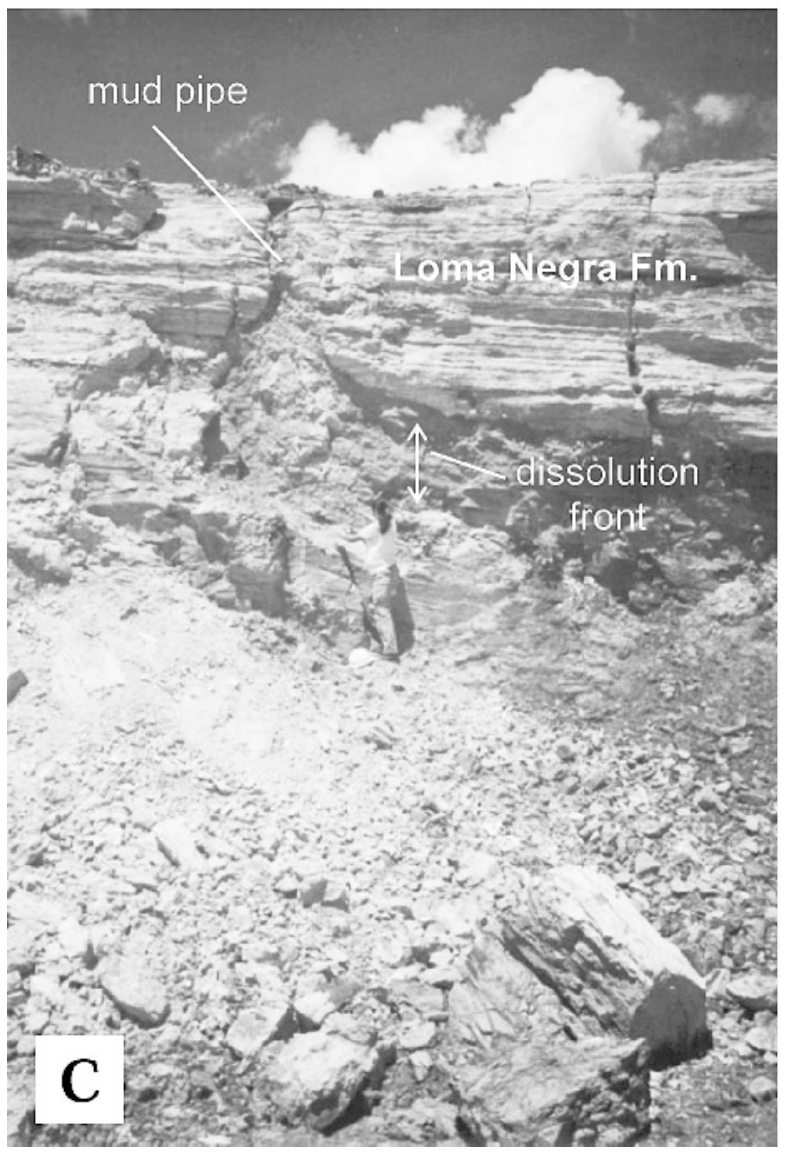



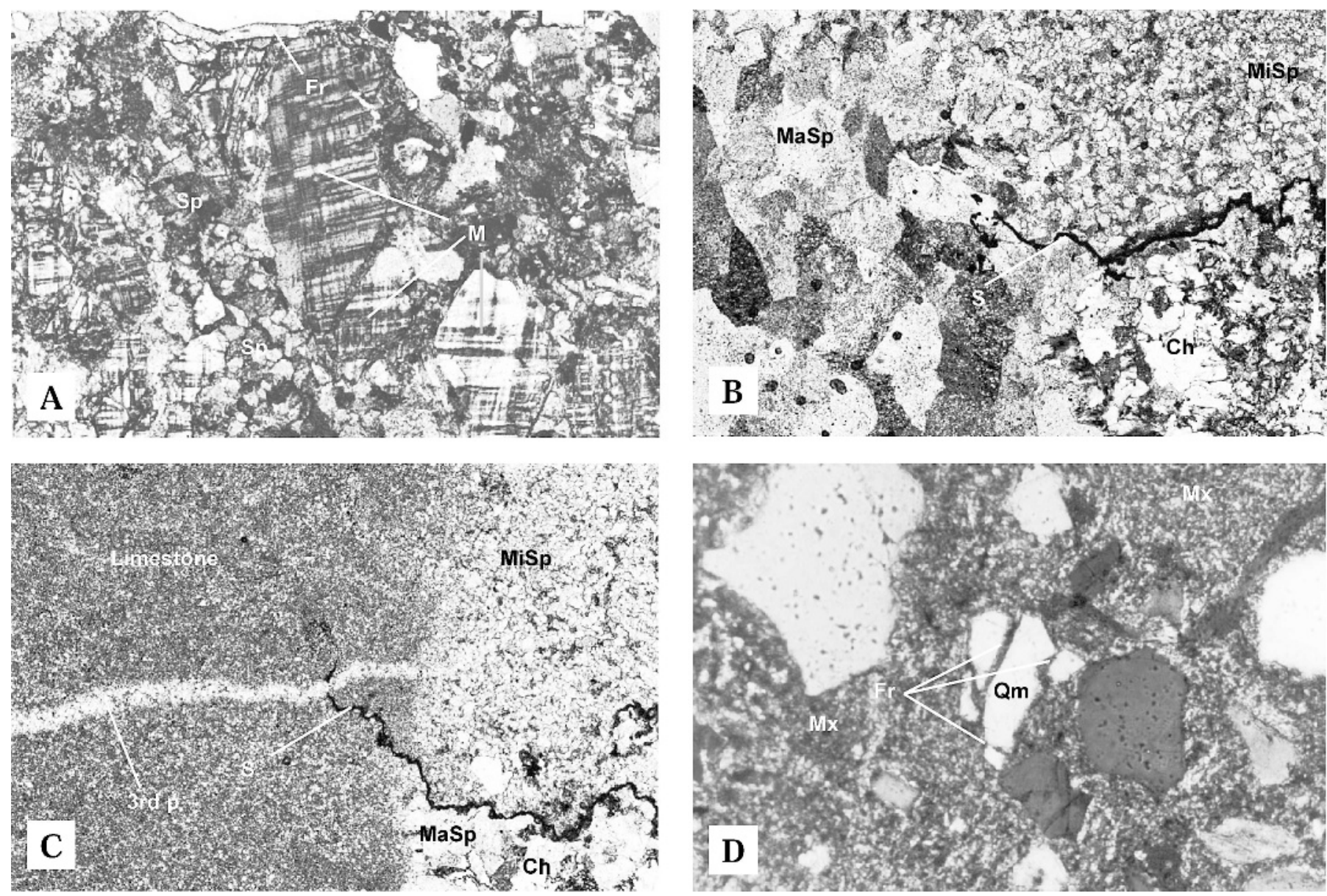

FIG. 5.-La Pampita quarry, Loma Negra Formation, Sierras Bayas area. A) Thin section of the polymictic orthoconglomerate. Microcline crystaloclast (M) encircled by coarse and fine sparite cement (Sp). Fractures are infilled by sparitic cement (Fr). Photograph taken under crossed polars, magnification $\times 100$. B) Detail of microsparite and macrosparite pulses (Mi-Sp and Ma-Sp, respectively) and chalcedony (Ch) void infilling. Stylolites (S) are cut by the growing of macrosparite cement. C) Close-up of the third pulse ( $3^{\text {rd }}$. . .) of sparite cement filling fractures and cutting the stylolites (S) at the contact between the limestone and the conglomerate. D) Thin section of the mud bed. Monocrystalline quartz $(\mathrm{Qm})$ fractured $(\mathrm{Fr})$ and displaced by injection matrix $(\mathrm{Mx})$ of $\mathrm{I} / \mathrm{S}$ composition. Photographs taken under crossed polars, magnification $\times 100$

cracks and pores as well as the grain fragmentation are also typical of mud injections, as stated by Pickering et al. (1988).

The preferential orientation of the clay particles in the matrix which fills the spaces between the disrupted grains and the tangential clay coatings observed around the grains is consistent with a process of mechanical infiltration. Additionally, the slickensides in the massive clay material are indicative of the rearrangement of the clay particles due to the expulsion of the solutions and the extrusion of the highly viscous remaining clay paste (Higgins and Saunders 1967).

The same structural style of vertical mud pipes found in different levels of the Loma Negra Formation (existence of cone-like structure within the adjacent limestone), the direct connection between some mud pipes and the underlying Olavarría Formation, and the dissolution features at the wall of the host limestone indicate that the upward mud injection originated in fluidization and transport of mud material from the underlying Olavarría Formation. It is also likely that mud injection was associated with strong fluid-rock interaction which resulted in the dissolution of calcite (by acidic fluids) and the crystallization of a random I/S (with 70-90\% smectite) at the expense of the ordered I/S (with $<15 \%$ smectite) previously formed during the peak diagenesis of the underlying Olavarría Formation. The processes described herein do not refer to weathering but to alteration by injection of overpressured fluids whose acidic properties originated from the presence of maturating organic matter in the source formation (the underlying Olavarría Formation).

Accumulation of overpressurized acidic compaction waters within mudstones located below a seal caprock (such as impermeable limestone) is a common feature during the burial diagenesis of sedimentary clay formations (cf. MacQuaker 1992, Worden and Burley 2003), and such

FIG. 4.-La Pampita quarry, Sierras Bayas area. A) I, Subhorizontal mud-bed deposit within the Loma Negra Formation (vertical arrows). II, Mud pipe associated with the mud bed (horizontal arrows). Upward deformation of the limestone strata at both sides of the clay pipe. (inclined arrows). B) Breaking and displacement of limestone blocks within the mud bed. Vertical fractures (Fr) infilled with calcite show only vertical displacement. C) Continuous dissolution front developed at the base of the Loma Negra Formation. Mud pipe within the Loma Negra Formation. 


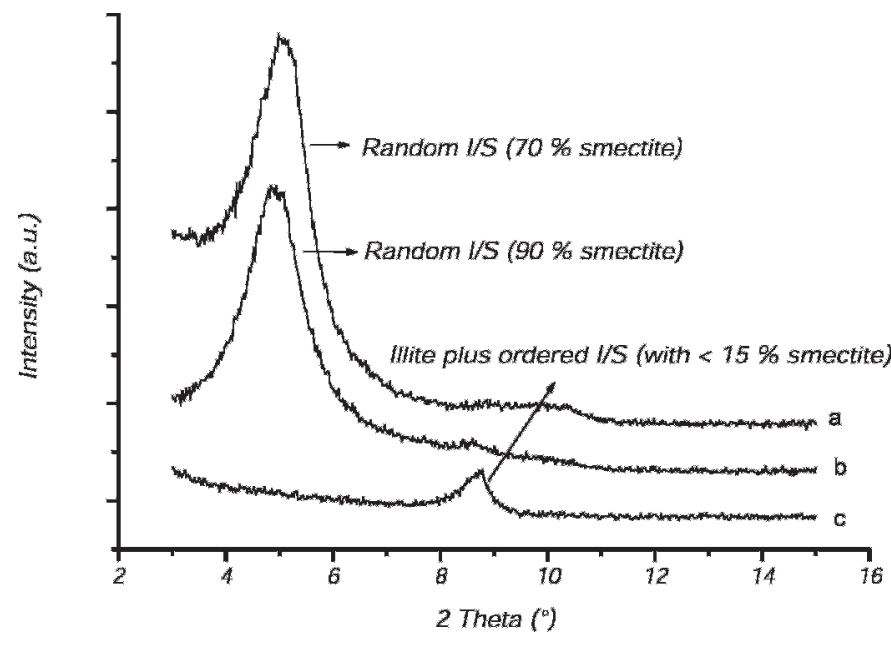

Fig. 6.-X-ray powder diffraction of clay minerals. La Pampita quarry, Sierras Bayas area. Mud bed (a). Random I/S ( $70 \%$ smectite). Mud pipe directly connected with the Olavarría Formation (b). Random I/S ( $90 \%$ smectite). Base of the Olavarría Formation (c). Illite + ordered I/S (with $<15 \%$ smectite).

a phenomenon can persist as long as the pore pressure at the top of the mudstone does not exceed the mechanical resistance of the seal. Basically, acidic fluids are released by maturing organic-rich shales during burial diagenesis (mesogenesis) and acidic pore solutions leach carbonate cement and grains. Also, connate waters expelled during diagenetic processes are well known to be acidic and rather reducing (Selley 1985). No measurement of the limestone permeability has been carried out, but petrographic observation shows that the beds are highly cemented (no visible porosity). Cracking of the seal caprock and related abrupt pressure release lead to squeezing out of the mud, resulting in the fluidization of the upper part of the Olavarría Formation bearing the previously trapped acidic compaction water. Acidic properties are, of course, interpretative. The reason why they are suspected to be acidic is that the base of the limestone overlying the Olavarría Formation is undoubtedly dissolved. Calcite remains highly soluble in acidic conditions, even at low temperatures.

The high smectite content ( 70 to $90 \%$ ) of the random I/S crystallized at the expense of the ordered I/S $(<15 \%$ smectite $)$ of the Olavarría Formation suggests that mud injection occurred at a temperature significantly lower than the maximum temperature attained during the peak diagenesis. This fact probably implies significant uplift of the sedimentary succession before the cracking of the limestone seal caprock. The precipitation of silica (now quartz) and calcite, which occurred in the late fractures and voids of the Loma Negra limestones, attests to supersaturation of fluids with these minerals, probably in response to pressure release in the system.

\section{Origin of Alunite and Aluminum Phosphate Sulfate (APS Minerals)}

Dill (2001) reviewed the geology of alunite and aluminum phosphate sulfates (APS minerals) of the alunite group and concluded that these minerals occur at low-pH conditions, in a wide range of environments near the surface of the Earth, including weathering, sedimentary, diagenetic, hydrothermal, and also metamorphic and igneous realms. $\mathrm{He}$ also stated that peraluminous parent rocks enriched in sulfur and/or phosphorus are a prerequisite for the formation of APS minerals that are stable over a large range of temperature (up to $400^{\circ} \mathrm{C}$ at moderately high fluid pressure of up to $1 \mathrm{kbar}$ ). Alunite and APS minerals with complex solid-solution series can form according to the local variation of $\mathrm{pH}$ and redox conditions in all these environments. Although all of these minerals



Fig. 7.- General view of the Las Aguilas Formation in the Cuchilla de Las Aguilas outcrops, Barker area. The sediments have been folded in response to a compressive strain developed parallel to the stratification, and three zones with distinctive colors have been identified: (1) an upper gray zone, (2) an intermediate bleached zone (light gray to white), at the base of which alunite lenses occur (Upper Lithofacies), and (3) a lower hematitized zone (reddish) also with alunite lenses at the top of the Middle Lithofacies.

are stable in acidic conditions, alunite is known to be stable at lower $\mathrm{pH}$ than those of APS (Stoffregen and Alpers 1987). Dill (2001) cited many tens of occurrences of alunite and APS minerals in sedimentary environments and noted that these minerals are commonly associated with clay minerals of the kaolinite group (kaolinite, halloysite, dickite) and with silica minerals (quartz, chalcedony, opal).

The geological process invoked by Dill (2001) for the origin of alunite and APS minerals in aluminous sedimentary rocks is the alteration of an aluminium silicate mineral at low-ph conditions. Such processes of waterrock interaction are initiated by a drastic lowering of the $\mathrm{pH}$ of the infiltrating fluids by the release of the sulfuric acid produced by the oxidation of iron sulfides (pyrite, marcasite) in the host rocks. The fact that very abundant pseudomorphous hematite after pyrite crystals has been observed in whitish clays associated with layers where both the alunite and the APS minerals occurred supports this hypothesis. According to the variations of the abundance of mineral phases observed in the different zones, it seems that most of the mineralogical reactions which occurred in the Cuchilla de Las Aguilas area can be summarized by the simplified reaction as follows:

2 illite +1 pyrite $+1 \mathrm{H}_{2} \mathrm{O}+3.75 \mathrm{O}_{2} \Rightarrow 1$ alunite +1 kaolinite (or halloysite) $+5 \mathrm{SiO}_{2}+0.5$ hematite

A similar reaction has already been proposed to interpret the occurrence of alunite in hydrothermally altered limestone and shale sequences hosting the Carlin type gold deposits (Arehart 1996). It should be noted that diaspore can be also a common by-product in this type of hydrothermal reaction which involved meteoric waters as the oxidizing agent (Dill 2001).

Aluminum phosphate sulfate minerals commonly crystallize during advanced argillic alteration (Stoffregen and Alpers 1987). However, according to the crystal-chemistry of svanbergite-Ce-florencite solid solution, the APS minerals from the Las Aguilas Formation probably crystallized in less acidic conditions than did alunite in more porous zones. Indeed, the composition of APS is highly dependent on $\mathrm{pH}$. The general trend is decreasing content in $\mathrm{S}$ and $\mathrm{Sr}$ and increasing $\mathrm{P}$ and LREE of APS with increasing $\mathrm{pH}$ (Gaboreau et al. 2005). According to 



Fig. 8.-Las Aguilas Formation. (Upper Lithofacies). A) Detail of alunite deposits at the base of the bleached zone. B) Silica nodule lenses (dark gray) in the blanched zone containing some alunite deposits. C) Cubes of pseudomorphous hematite after pyrite crystals disseminated in the bleached whitish claystones (Py).

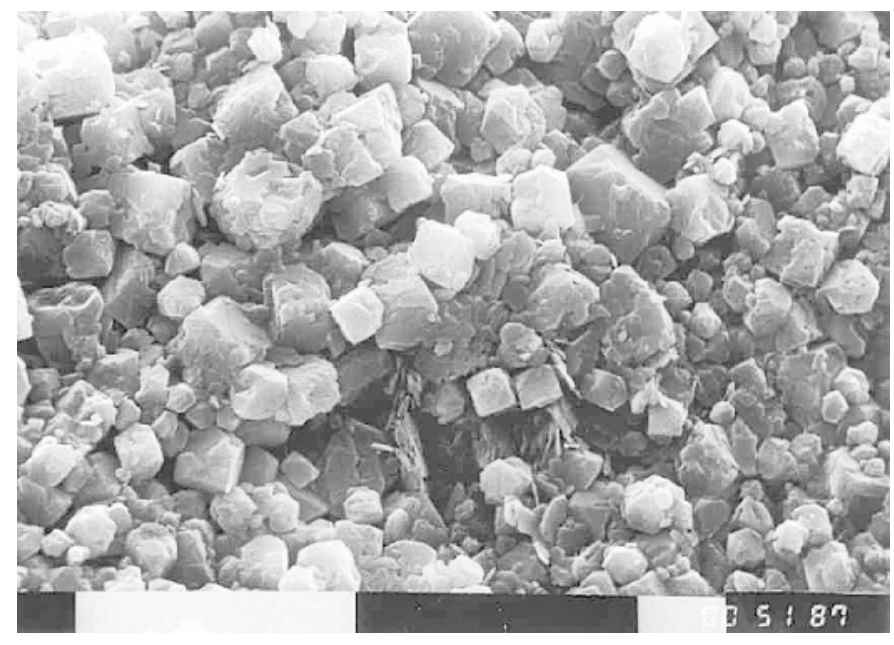

Fig. 9.- Scanning electron micrograph of alunite. Middle Lithofacies, Las Aguilas Formation, Cuchilla de Las Aguilas, Barker area, $\times$ 4000. Scale bar: $10 \mu \mathrm{m}$. this scheme, it seems reasonable to suggest that the APS observed in the less porous zones of the bleached zone represent the alteration products of detrital monazite, coming from the basement rocks and some of the Alsilicate of the sediments (possibly feldspars) by acidic solutions in relatively closed local systems. Indeed, a low water/rock ratio (due to low porosity and poor renewal of solutions) promoted the high chemical activity of $\mathrm{PO}_{3}{ }^{3-}$ and the rapid increase in $\mathrm{pH}$ conditions necessary to stabilize the APS of the svanbergite-florencite solid-solution as the alteration of monazite progressed.

\section{Evidence of Basin Inversion in the Tandilia System: Diagenetic Stages}

The physicochemical conditions previously mentioned would easily be satisfied during a tectonic event like a structural inversion. Basin inversion causes uplift of the sediments and erosion of a part of the sedimentary succession. Uplift and erosion are the best way to promote the cracking of the seal caprock because they increase the local pressure gradient at the boundary of the overpressured compartments (leading to the overcoming of the mechanical resistance of the seal).

Basin inversion can begin at any time, depth, or temperature during the basin history, and the uplift range can be highly variable according to the tectonic setting. It is not possible to accurately determine the degree of uplift when mud injection occurred in the limestones of the Loma Negra Formation. 




FIG. 10.-Microprobe analyses of APS minerals, Las Aguilas Formation, Cuchilla de Las Aguilas, Barker area.
The findings and characteristics of mud beds and pipes in the Loma Negra Formation, the direct connection of the latter with the Olavarría Formation, the transformation of ordered I/S (with $<15 \%$ smectite) into a more smectitic random $\mathrm{I} / \mathrm{S}$ ( $90 \%$ smectite) in the mud bed and pipes and in the unconformity between the Olavarría and the Loma Negra formations (dissolution front) lead us to propose a paragenetic sequence for the Olavarría and the Loma Negra formations (Fig. 13A) based, in part, on Worden and Burley (2003) and Burley and MacQuaker (1992). This area was affected by a compressive tectonic stage, basin uplift, erosion, faulting, and folding of sedimentary strata. The major alteration processes consisted of fracturing and injection of overpressured fluidized sediments within the limestones of the Loma Negra Formation.

In the Barker area, the identification of oxidized pyrite (pseudomorphous hematite after pyrite) in the Las Aguilas Formation, together with the association of APS minerals (alunite, svanbergite-Ce-florencite) kaolinite, halloysite, diaspore, and goethite, allow us to propose a paragenetic sequence (Fig. 13B) based, in part, on Worden and Burley (2003) and Burley and MacQuaker (1992). Infiltration of oxidizing fluids

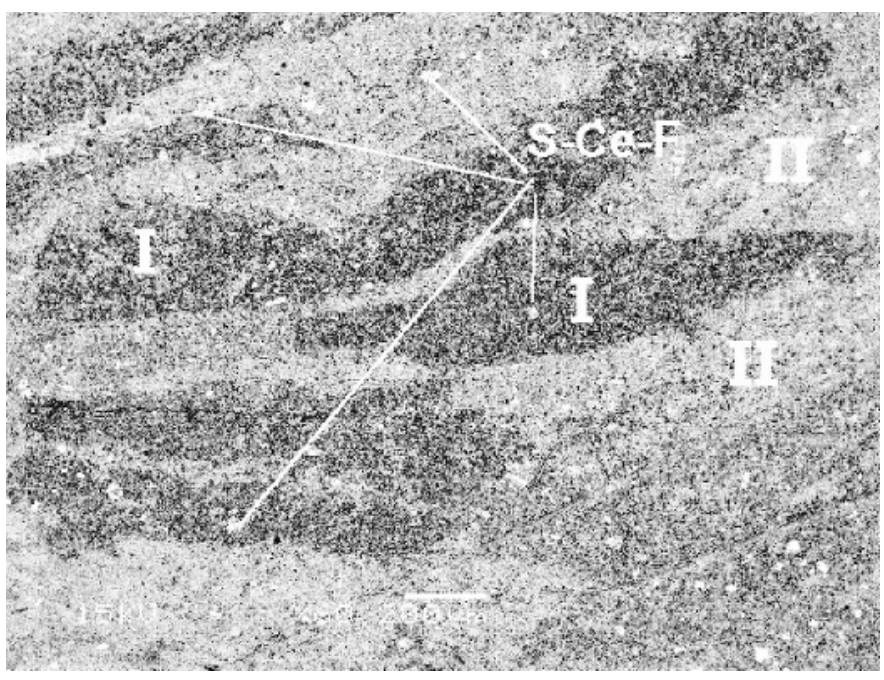

Fig. 11.-Backscattered electron image of clay deposits bearing APS minerals. Svanbergite-Ce-florencite (S-Ce-F). (I) High-porosity zones with alunite, halloysite, diaspore, and svanbergite-Ce-florencite. (II) Low-porosity zones rich in pyrophyllite, kaolinite, micas, svanbergite-Ce-florencite, and heavy metals. Middle Lithofacies, Las Aguilas Formation, Cuchilla de Las Aguilas, Barker area. was able to strongly dissolve and oxidize the euhedral diagenetic pyrite within the claystones of the Las Aguilas Formation. Basin inversion, uplift, erosion and infiltration of surficial oxidizing waters in previously more deeply buried sediments belong to the history of most of the sedimentary basins in the world. These phenomena are particularly well developed near the basin margins and are reported in literature as telodiagenesis (Worden and Burley 2003). K-Ar dating for the three samples of alunite provides an age of $254 \pm 7 \mathrm{Ma}$ for the occurrence of the telodiagenetic stage in the Tandilia basin.

According to Burley and Macquaker (1992), the period of time during which the basin-margin sequences can be subjected to telodiagenesis and hence the intensity of the related alteration processes depends on the timing of structural inversion. We have no reliable data on the origin of the infiltrated oxidizing waters which initiated the advanced argillic alteration in the Las Aguilas Formation. However, all the elements of the above discussion lead us to consider the hypothesis of infiltration of meteoric water as a realistic one.

The fact that the Las Aguilas Formation has been correlated with the Olavarría Formation (Poiré and Spalletti 2005) would reinforce the hypothesis that a concomitant telodiagenetic stage occurred in both units.

\section{Geodynamic Evolution of the Tandilia System}

The results of the present study provide an additional stage in the tectonosedimentary evolution proposed by Iñíguez et al. (1989). In his

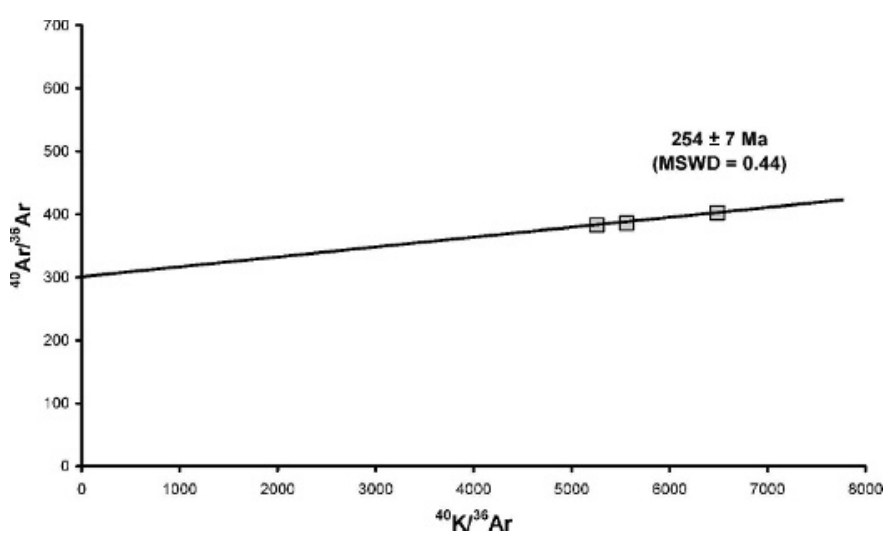

FIG. 12.- $\mathrm{K}-\mathrm{Ar}$ isochron diagram of the three analyzed alunite samples from the Middle Lithofacies, Las Aguilas Formation, Cuchilla de Las Aguilas, Barker area. 


\begin{tabular}{|c|c|c|c|c|}
\hline \multicolumn{2}{|c|}{ OBSERVATIONS } & \multirow[t]{2}{*}{ PROCESSES } & \multirow{2}{*}{\multicolumn{2}{|c|}{$\begin{array}{c}\text { GEOLOGICAL } \\
\text { HISTORY STAGE }\end{array}$}} \\
\hline MINERALS & STRUCTURES & & & \\
\hline \multirow[t]{2}{*}{$\mathrm{I} / \mathrm{S}(<15 \% \mathrm{Sm})$} & $\begin{array}{l}\text { Overlying limestone } \\
\text { strata dissolution }\end{array}$ & \begin{tabular}{|l|} 
Compaction \\
Fluid overpressure \\
Organic maturation
\end{tabular} & Burial sta & \\
\hline & $\begin{array}{l}\text { Faults in the } \\
\text { limestones }\end{array}$ & SW-NE Compression & $\begin{array}{l}\text { Tectonic } \\
\text { Ventania }\end{array}$ & effect of \\
\hline ISS (90\% Sm) & $\begin{array}{l}\text { Mud pipes with } \\
\text { limestone blocks }\end{array}$ & $\begin{array}{l}\text { Injection of } \\
\text { overpressured mud } \\
\text { Disruption and collapse } \\
\text { of limestone blocks }\end{array}$ & Uplift & \multirow[t]{2}{*}{$\begin{array}{l}\text { Telodia- } \\
\text { genesis }\end{array}$} \\
\hline $\begin{array}{l}\text { Secondary calcite } \\
\text { Chalcedony }\end{array}$ & $\begin{array}{l}\text { Local graben } \\
\text { (extension) }\end{array}$ & Release of fluid pressure & Erosion & \\
\hline
\end{tabular}

A

\begin{tabular}{|l|l|l|l|l|}
\hline \multicolumn{2}{|c|}{ OBSERVATIONS } & \multicolumn{1}{c|}{ PROCESSES } & \multicolumn{2}{c|}{$\begin{array}{l}\text { GEOLOGICAL } \\
\text { HISTORY STAGE }\end{array}$} \\
\hline $\begin{array}{l}\text { I/S (<15\% Sm) } \\
\text { Quartz overgrowth } \\
\text { Pyrite }\end{array}$ & Stratification & $\begin{array}{l}\text { Compaction } \\
\text { Organic maturation }\end{array}$ & Burial stage \\
\hline $\begin{array}{l}\text { Kaolinite - halloysite } \\
\text { alunite, APS, diaspore } \\
\text { hematite, goethite }\end{array}$ & $\begin{array}{l}\text { Fseudomorphous } \\
\text { hematite after pyrite } \\
\text { Alunite lenses }\end{array}$ & $\begin{array}{l}\text { Invasion of oxidative } \\
\text { fluids (meteoric) }\end{array}$ & $\begin{array}{l}\text { Uplift } \\
\text { Erosion }\end{array}$ & $\begin{array}{l}\text { Telodia- } \\
\text { genesis }\end{array}$ \\
\hline
\end{tabular}

B

FIG. 13.-A) Summary of the diagenetic stages proposed for the Sierras Bayas area (Olavarría and Loma Negra formations). B) Summary of the diagenetic stages proposed for the Cuchilla de Las Aguilas, Barker area (Las Aguilas Formation). model (Fig. 14A), Iñíguez et al. (1989) proposed that from 900 to $700 \mathrm{Ma}$ the sedimentary sequences experimented only weak epeirogenic movements. Consequently, the sediments were not deformed and remained flat-lying. The orogenic movements produced by the Brazilian cycle $(600$ $\mathrm{Ma}$ ) affected the crystalline basement and the sedimentary cover as well as producing faulting with important vertical and horizontal displacement in response to SW oriented stress. A series of horst and graben structures were formed. In some cases, the upthrown blocks were completely eroded. The crystalline basement rocks were exposed while the depressed ones preserved most of the sedimentary cover, as occurred in the areas of Sierras Bayas, Barker, and San Manuel (60 km to the SE of Barker). Presumably, the peneplanation process occurred during the
Cambrian. At the same time, the basement of the Balcarce-Mar del Plata area (100 and $150 \mathrm{~km}$, respectively, to the SE of Barker) experienced subsidence, having been a positive area, at least, during the deposition of the Neoproterozoic units.

Shallow burial $(2-3 \mathrm{~km})$ took place between approximately 400 and $250 \mathrm{Ma}$. The additional stage in the tectonosedimentary evolution of the Sierras Bayas and Barker-Cuchilla de Las Aguilas areas is presented in Figure 14B. The telodiagenetic stage occurred during the middle Permian (near $254 \mathrm{Ma}$ ) in response to a renewed basin inversion, uplift, and erosion of the upper sedimentary units of the basin. Consequent transfer (and possible mixing) of fluids of both diagenetic and meteoric origin were involved along structural discontinuities previously created by the

TABle 1.-K-Ar data for three alunite samples containing impurities of kaolinite and halloysite. Middle Lithofacies, Las Aguilas Formation, Cuchilla de Las Aguilas, Barker area. Alu. 1, 2, 3, samples analyzed.

\begin{tabular}{|c|c|c|c|c|c|c|}
\hline Samples analized & $\mathrm{K}_{2} \mathrm{O}(\%)$ & ${ }^{40} \mathrm{Ar} \operatorname{rad}\left(10^{-6} \mathrm{~cm}^{3} / \mathrm{g} \mathrm{STP}\right)$ & ${ }^{40}$ Ar rad (\%) & ${ }^{40} \mathrm{Ar} /{ }^{36} \mathrm{Ar}$ & ${ }^{40} \mathrm{~K} /{ }^{36} \mathrm{Ar}$ & Age in $\mathrm{Ma}( \pm 2 \sigma)$ \\
\hline Alu 1 & 0.78 & 7.06 & 23.50 & 386 & 5.561 & $261(13)$ \\
\hline Alu 2 & 0.77 & 7.12 & 22.90 & 383 & 5.259 & $266(15)$ \\
\hline Alu 3 & 0.78 & 7.06 & 26.40 & 402 & 6.489 & $261(18)$ \\
\hline
\end{tabular}



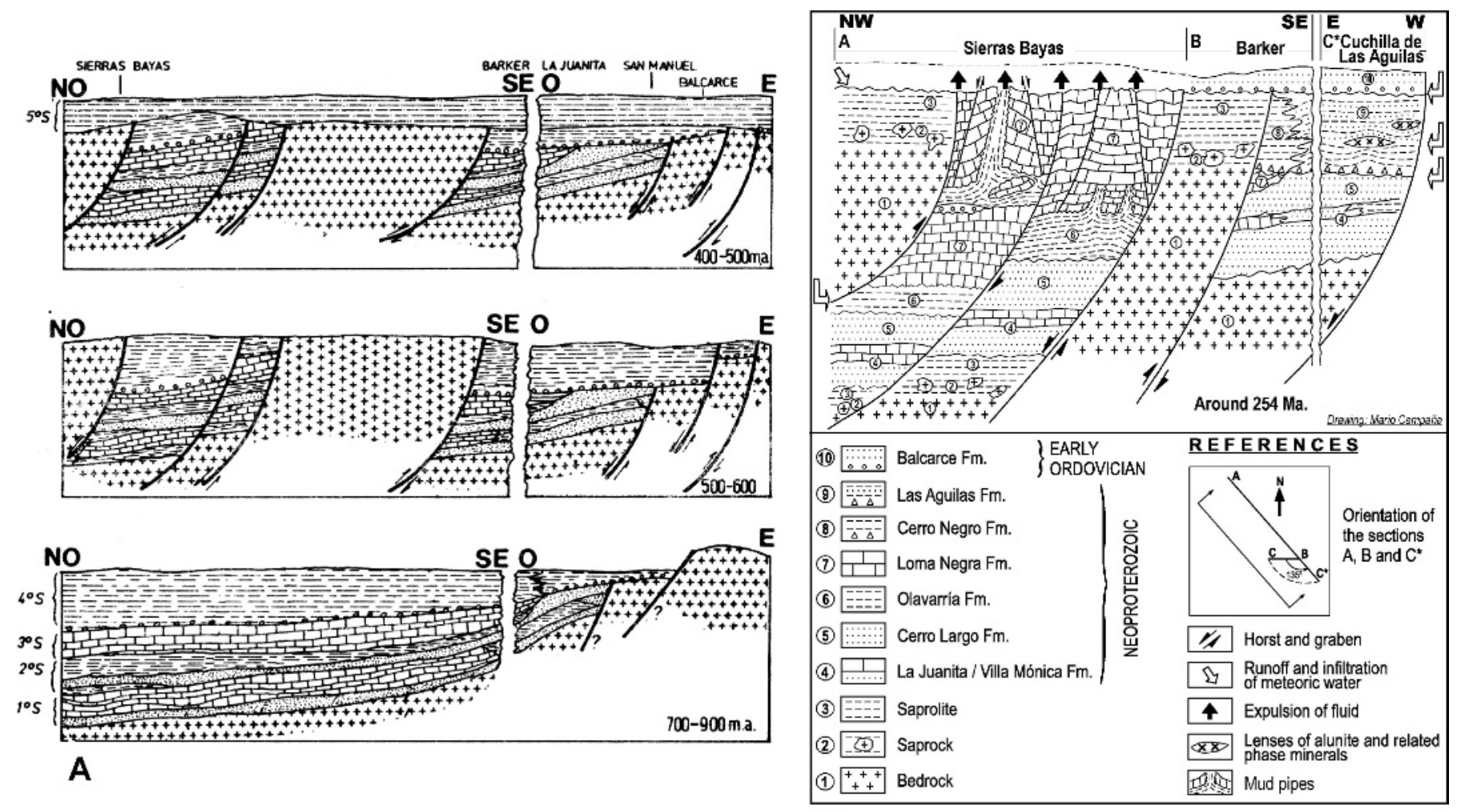

B

Fig. 14.-A) Scheme of the tectonosedimentary evolution of the Tandilia Basin from Sierras Bayas to Balcarce areas. Taken from Iñíguez et al. (1989). $1^{\circ}$ S: First sedimentary sequence: Cuarcitas Inferiores and dolomites. $2^{\circ}$ S: Second sedimentary sequence: Cuarcitas Superiores and overlying claystone and siltstone facies: Cerro Largo Formation. $3^{\circ} \mathrm{S}$ : Third sedimentary sequence: Loma Negra Formation. $4^{\circ} \mathrm{S}$ : Fourth sedimentary sequence: Las Aguilas-Cerro Negro formations. $5^{\circ}$ S: Fifth sedimentary sequence: Balcarce Formation. B) New proposal for the tectonosedimentary evolution of the Sierras Bayas and Barker-Cuchilla de Las Aguilas areas, Tandilia Basin, representing a telodiagenetic stage in the model of Iñíguez et al. (1989), which occurred during the middle Permian (around $254 \mathrm{Ma}$ ). The sketch is composed of two sections: A-B (Sierras Bayas-Barker) and B-C*: (Barker-Cuchilla de Las Aguilas). For a better understanding and a clear graphic representation, section $\mathrm{B}-\mathrm{C}$ has been revolved $135^{\circ}\left(\mathrm{C}^{*}\right)$ on a plane following the $\mathrm{A}-\mathrm{B}$ section (see references).

compressive regional forces and reopened by decompression. It should be noted that the new age obtained here for the alteration processes agrees well with the Permian age proposed by von Gosen and Buggisch (1989) and Varela et al. (1985) for the main deformation and folding stage of the Ventania System.

Vertical movements have prevailed since the Precambrian (Brazilian orogenic cycle) and during most of the geological history of this blockmountain system. Because of this, the sedimentary cover has probably been re-buried and re-exhumed several times.

On the other hand, based on recent drilling data, Lesta and Sylwan (2005) assumed that Tandilia was a positive area subsequent to the Ordovician. On the basis of this information and the age of the alunite, we also postulate that after the uplift and deformational phase occurred during the middle Permian, the Tandilia System has remained as a positive area.

\section{CONCLUSIONS}

Mud beds and pipes in the Loma Negra Formation, connected with the Olavarría Formation, together with the emplacement of alunite and aluminum phosphate sulfate (APS minerals) in the claystones of the Las Aguilas Formation (all Neoproterozoic) bearing advanced argillic alteration within bleached meter-thick zones, indicate that the Neoproterozoic sedimentary sequences of the Tandilia System underwent a water-rock interaction event which postdated the peak burial-related diagenesis of the basin.
In the Sierras Bayas area, this alteration stage seems to have been structurally controlled by a compressive tectonic phase (basin uplift, erosion of upper sedimentary strata, faulting, and folding). The major alteration processes consisted of fracturing and injection of overpressured fluidized sediments within the limestones of the Loma Negra Formation (development of a dissolution front at the contact between the Olavarría and the Loma Negra formations and transformation of ordered I/S with $<15 \%$ smectite into random I/S with $90 \%$ smectite and mud injection).

On the other hand, in the Barker area, infiltration of meteoric oxidizing fluids was able to strongly dissolve and oxidize diagenetic pyrite in the claystones of the Las Aguilas Formation, forming alunite and APS minerals (svanvergite-Ce-florencite), halloysite, diaspore, kaolinite, hematite, and goethite.

All of these events are interpreted to be a response to $2-3 \mathrm{~km}$ burial, uplift, and erosion of the upper sedimentary units of the basin and intrusion (Olavarría and Loma Negra formations) or expulsion (Las Aguilas Formation) of fluids in the exhumed rocks during a telodiagenetic stage. Surface and drilling data suggest that The Tandilia System has remained as a positive area subsequent to the Ordovician.

$\mathrm{K}-\mathrm{Ar}$ data of alunite in the Las Aguilas Formation provides an age of $254 \pm 7 \mathrm{Ma}$ (middle Permian) for the occurrence of a telodiagenetic stage in the Tandilia basin.

The new age obtained here for the alteration processes agrees well with the Permian age proposed by von Gosen and Buggisch (1989) and Varela et al. (1985) for the main deformation and folding stage of the Ventania 
System, located $150 \mathrm{~km} \mathrm{SW}$ of the study area, relating the deformation of the Ventania System with the uplift, erosion, and telodiagenetic stage that occurred in the Tandilia System.

\section{ACKNOWLEDGMENTS}

The funding was provided by an ECOS-SETCYP international program, the Comisión de Investigaciones Científicas, Provincia de Buenos Aires, the Facultad de Ciencias Naturales y Museo de La Plata and the UMR 6532 CNRS (France). The authors want to acknowledge Olavarría Loma Negra CIASA Co. through its Manager J. Martínez, and R. Iturriza, and J. Pellegrini, for permission to visit repeatedly the La Pampita quarry, and for their kind concern and attention. We also thank M.S. Conconi for her assistance in the use of software for editing the figures. We also thank Norbert Clauer and Raymond Wendling of the Centre de Géochimie de la Surface of the University of Strasbourg for the K-Ar measurements. The authors acknowledge the Journal of Sedimentary Research Co-Editor Kitty Milliken, the Associate Editor Richard H. Worden, the Corresponding Editor John Southard, and the reviewers Susanne Schmid and Helen Lever for their valuable comments and suggestions.

The data described in this paper have been archived, and are available in digital form, at the SEPM data archive at http://www.sepm.org/archive/ index.html.

\section{REFERENCES}

AceÑolaza, F.G., 1978, El Paleozoico inferior de Argentina según sus trazas fósiles: Ameghiniana, v. 5, p. 3-10.

Ahmad, A.H.M., And Bhat, G.M., 2006, Petrofacies, provenance and diagenesis of the Dhosa Sandstone Member (Chari Formation) at Ler, Kachchh sub-basin, Western India: Journal of Asian Earth Sciences: Journal of Asian Earth Sciences, v. 27, p. 857-872.

Amos, A., Quartino, B., And Zardini, R., 1972, El grupo La Tinta, Provincia de Buenos Aires, Argentina. Paleozoico o Precámbrico: 25 Congreso Brasilero de Geología, Rio de Janeiro, Annais, p. 211-221.

Andreis, R.R., AND ZALBA, P.E., 1989, Estratigrafía y paleogeografía de las secuencias cuarciticas al oeste de Barker (Buenos Aires, Argentina): 1st Jornadas Geológicas Bonerenses, Actas, p. 909-929.

Andreis, R.R., Zalba, P.E., IÑíguez Rodríguez, A.M., and Morosi, M.E., 1996, Estratigrafía y evolución paleoambiental de la sucesión superior de la Formación Cerro Largo, Sierras Bayas (Buenos Aires, Argentina): $6^{\circ}$ Reunión Argentina de Sedimentología, Bahía Blanca, Actas, p. 293-298.

Arehart, G.B., 1996, Origin and characteristics of sediment-hosted disseminated gold deposits: a review: Ore Geology Reviews, v. 11, p. 383-403.

Bonhomme, M., and Cingolani, C., 1978, First isotopic dating of Upper Precambrian sediments in the Province of Buenos Aires: 4th International Conference on Geochronological and Isotopic Geology, Short Papers, Geological Survey, 79-701, p. 45-46.

Bonhomme, M., and Cingolani, C., 1980, Mineralogía y geocronología Rb-Sr y K-Ar de fracciones finas de la Formación La Tinta, Provincia de Buenos Aires: Asociación Geológica Argentina, Revista, v. 35, p. 519-530.

Bonhomme, M., Thuizat, R., Pinault, Y., Clauer, N., Wendling, R., and Winkler, R., 1975, Méthode de datation potassium-argon: appareillage et technique: Institut Géologie, Strasbourg, Notes Techniques, v. 3, 35 p.

Borrello, A.V., 1966, Trazas, restos tubiformes y cuerpos fósiles problemáticos de la Formación La Tinta, in Paleontografía Bonaerense, Comisión de Investigaciones Científicas de la Provincia de Buenos Aires, La Plata,, v. 5, p. 1-42.

Burley, S.D., and MacQuaker, J.H.S., 1992, Authigenic clays, diagenetic sequences and conceptual diagenetic models in contrasting basin-margin and basin-center North Sea Jurassic sandstones and mudstones, in Houseknecht, D.W., and Pittman, E.D., eds., Origin, Diagenesis and Petrophysics of Clay Minerals in Sandstones, SEPM, Special Publication 47, p. 81-110.

Cazenueve, H., 1967, Edades isotópicas del basamento de la Provincia de Buenos Aires: Ameghiniana, n. 5, p. 3-10.

Cingolani, C., 1988, Resultados geocronológicos en niveles pelíticos intercalados en las dolomías de Sierras Bayas (Grupo La Tinta), Provincia de Buenos Aires: 2nd Jornadas Geológicas Bonerenses, Actas, p. 283-289.

Cingolani, C., and Bonhomme, M., 1982, Geochronology of La Tinta Upper Proterozoic sedimentary rocks, Argentina: Precambrian Research, v. 18, p. 119 132.

Dalla Salda, L., And IÑíguez, A.M., 1979, “La Tinta,” Precámbrico y Paleozoico de Buenos Aires: 7 Congreso Geológico Argentino, Buenos Aires, v. 1, p. 539-550.

del VALLe, A., 1987, Nuevas trazas fósiles en la Formación Balcarce, Paleozoico inferior de las Sierras Septentrionales. Su significado cronológico y ambiental: Museo de La Plata, Revista, Nueva Serie, v. 9, p. 19-41.

DE Almeida, F., 1971, Geochronological division of the Precambrian of South America: Revista Brasilera de Geociencias, v. 1, p. 3-21.
Del Valle, A., 1990, Paleogeografía de la cuenca de depositación de la Formación Balcarce (Ordovícico inferior), Tandilia, Argentina: 3 Reunión Argentina de Sedimentología, Actas, p. 102-108.

Dill, H.G., 2001, The geology of aluminium phosphates and sulphates of the alunite group: a review: Earth Science Reviews, v. 53, p. 35-93.

Di Paola, E., And Marchese, H.G., 1974, Relación entre la tectosedimentación, litología y mineralogía de arcillas del Complejo Buenos Aires y la Formación La Tinta (Provincia de Buenos Aires): Asociación Argentina de Mineralogía, Petrología y Sedimentología, Revista, v. 5, p. 45-58.

Dristas, J.A., AND Frisicale, M.C., 1996, Geochemistry of an altered pyroclastic suite interbedded in the sedimentary cover of the Tandilia Area, Buenos Aires, Argentina: Zentralblatt für Geologie und Paläontologie, Teil 1, v. 7-8, p. 659-675.

Dristas, J.A., AND Frisicale, M.C., 2003, Two types of hydrothermal clay deposits in the south-east area of Tandilia. Buenos Aires Province, Argentina, in Domínguez, E.A., Mas, G.R., and Cravero, F., eds., 2001, A Clay Odyssey: Amsterdam, Elsevier, p. 85-92.

Frisicale, M.C., AND Dristas, J.A., 2000, Génesis de los niveles arcillosos de la Sierra de La Tinta, Tandilia: Asociación Geológica Argentina, Revista, v. 55, p. 3-14.

Gaboreau, S., Beaufort, D., Vieillard, P., Patrier, P., and Bruneton, P., 2005, Aluminum phosphates sulphates minerals associated with Proterozoic unconformitytype uranium deposits in the East Alligator Rivers Uranium Field, Northern Territory, Australia: Canadian Mineralogist, v. 43, p. 795-809.

GrigoR'EV, D.P., 1965, Ontogeny of Minerals: Israel Program for Scientific Translations, S. Marson, Jerusalem, $250 \mathrm{p}$

Halpern, M., AND Linares, E., 1970, Edad rubidio-estroncio de las rocas graníticas del basamento cristalino del área de Olavarría, Provincia de Buenos Aires, República Argentina: Asociación Geológica Argentina, Revista, v. 25, p. 303-306.

Hemingway, J.E., AND RiddleR, J., 1982, Basin inversión in the North Yorkshire: Institute of Mining and Metallurgy, Transactions, Section B, Applied Earth Science, v. 91, p. $175-186$

Higgins, G.E., And Saunders, J.B., 1967, Report on 1964 Chatham Mud Island, Erin Bay, Trinidad, West Indies: American Association of Petroleum Geologists, Bulletin, v. 51, p. $55-64$

1NígueZ, A.M., 1965, Mineralogía de algunos yacimientos de arcillas de la Provincia de Buenos Aires [Tesis Doctoral]: Facultad de Ciencias Naturales y Museo de La Plata, $89 \mathrm{p}$.

lNíguez Rodríguez, A.M., and Zalba, P.E., 1974, Nuevo nivel de arcilitas en la zona de Cerro Negro, Partido de Olavarría, Provincia de Buenos Aires. La Plata: Laboratorio de Ensayo de Materiales e Investigaciones Tecnológicas, serie 2, v. 264, p. 95-100.

Iñiguez, A.M., Del Valle, A., Poiré, D., Spalletti, L., And Zalba, P.E., 1989, Cuenca Precámbrico/Paleozoica inferior de Tandilia, Provincia de Buenos Aires, in Chebli, G., and Spalletti, L., eds., Cuencas Sedimentarias Argentinas: Universidad Nacional de Tucumán, Instituto Superior de Correlación Geológica, Serie de Correlación Geológica, v. 6, p. 245-263.

Iñiguez, A.M., Manassero, M., Poiré, D., And MagGi, J., 1996, Génesis y procedencia de sedimentitas cuarzosas del área de Olavarría, Provincia de Buenos Aires: 6 Reunión Argentina de Sedimentología, Bahía Blanca, Actas, v. 1, p. 61-66.

Lesta, P., and Sylwan, C., 2005, Cuenca de Claromecó, in Chebli, G., Cortiñas, J., Spalletti, L., Legarreta, L., and Vallejo, E., eds., VI Congreso de Exploración y Desarrollo de Hidrocarburos, "Ampliando las Fronteras,", p. 217-231.

LUDwIG, K.R., 1991, ISOPLOT: A plotting and regression program for radiogenic isotope data, version 2.71: U.S. Geological Survey, Open-File Report 91-445, p. 91-445.

Massabié, A.C., Amos, A.J., And Iturriza, R., 1992, Diapirismo arcilítico tectoinducido, Sierras Bayas, Provincia de Buenos Aires: Asociación Geológica Argentina, Revista, v. 47, p. 389-397.

Morton, N., 1987, Jurassic subsidence history in the Hebrides, N. W. Scotland: Marine and Petroleum Geology, v. 4, p. 226-242.

Murray, H.H., 1976, The Georgia sedimentary kaolins: 7th Symposium on Kaolin Genesis, International Geological Correlation Program, Committee on Correlation of Age and Genesis of Kaolin, Tokyo, p. 114-125.

Pickering, K.T., Agar, S.M., and OGawa, Y., 1988, Genesis and deformation of mud injections containing chaotic basalt-limestone-chert associations: examples from the southwest Japan forearc: Geology, v. 16, p. 881-885.

PoIRé, D., 1993, Estratigrafía del Precámbrico sedimentario de Olavarría, Sierras Bayas, Provincia de Buenos Aires, Argentina: 12 Congreso Geológico Argentino y 2 Congreso de Exploración de Hidrocarburos, Mendoza, Actas, v. 2, p. 1-11.

Poiré, D., AND Spalletti, L., 2005, La cubierta sedimentaria Precámbrica-Paleozoica inferior del sistema de Tandilia, in de Barrio, R.E., Etcheverry, H.O., Caballé, M.F., and Llambías, E., eds., Geología y Recursos Minerales de la Provincia de Buenos Aires: 16 Congreso Geológico Argentino, La Plata, Relatorio, v. 4, p. 51-68.

Rapela, C.W., Dalla Salda, L., and Cingolani, C., 1974, Un intrusivo básico ordovícico de la Formación La Tinta (Sierras de los Barrientos, Provincia de Buenos Aires, Argentina): Asociación Geológica Argentina, Revista, v. 29, p. 319-331.

REYNOLDS, R., 1985, Newmod, a computer program for the calculation of onedimensional diffraction patterns of mixed-layer clays: R.C. Reynolds, Jr., 8 Brook Drive, Hanover, New Hampshire, U.S.A.

Scotchman, I.C., 1991a, The geochemistry of concretions from the Kimmeridge Clay Formation of southern and eastern England: Sedimentology, v. 38, p. 79-106.

Scotchman, I.C., 1991b, Kerogen facies and maturity of the Kimmeridge Clay Formation of southern and eastern England: Marine and Petroleum Geology, v. 8, p. 278-295. 
Sellés Martínez, J., 1994, Lineamientos estructurales y evolución extensional de la plataforma Neoproterozoica-Eopaleozoica de las Sierras Septentrionales de la Provincia de Buenos Aires, Argentina: Revista Brasileira de Geociências, v. 23, p. 289-295.

Selley, R.C., 1985, Elements of Petroleum Geology: San Francisco, W.H. Freeman, $449 \mathrm{p}$.

Steiger, R.H., AND Jäger, E., 1977, Convention on the use of decay constants in geo and cosmochronology: Earth and Planetary Science Letters, v. 36, p. 359-362.

Stipanicic, M.E., AND Linares, E., 1969, Edades radimétricas determinadas para la República Argentina y su significado geológico: Academia Nacional de Ciencias Córdoba, Boletín, v. 47, p. 51-96.

Stoffregen, R.E., and Alpers, C.N., 1987, Woodhouseite and svanbergite in hydrothermal ore deposits: products of apatite destruction during advanced argillic alteration: Canadian Mineralogist, v. 25, p. 201-211.

Varela, R., Dalla Salda, L., and Cingolani, C., 1985, Estructura y composición geológica de las sierras Colorada, Chasicó y Cortapié, Sierras Australes de Buenos Aires: Asociación Geológica Argentina, Revista, v. 40, p. 254-261.

Varela, R., Cingolani, C., and Dalla Salda, L., 1988, Geocronología Rb-Sr en granitoides del basamento de Tandil, Provincia de Buenos Aires, Argentina: 2 Jornadas Geológicas Bonaerenses, Actas, p. 291-305.

von Gosen, W., AND Buggisch, W., 1989, Tectonic evolution of the Sierras Australes fold and thrust belt, Buenos Aires Province, Argentina: An outline: Zentralblatt für Geologie und Paläontologie, Teil 1, v. 5-6, p. 947-958.

Worden, R.H., And Burley, S.D., 2003, Sandstone Diagenesis: the evolution of sand to stone: in Burley, S.D., and Worden, R.H., eds., Sandstone Diagenesis: Recent and Ancient: International Association of Sedimentologists, Blackwell Publishing, Reprint Series, v. 4 , p. $3-44$

ZalBA, P.E., 1979, Clay deposits of Las Águilas Formation, Barker, Buenos Aires Province, Argentina: Clays and Clay Minerals, v. 27, p. 433-439.
ZaLba, P.E., 1982, Scan electron micrographs of clay deposits of Buenos Aires Province, Argentina: International Clay Conference, Bologna-Pavia, Italy: Developments in Sedimentology, Amsterdam, Elsevier, v. 35, p. 513-528.

ZALBA, P.E., AND ANDREIS, R.R., 1998, Basamento cristalino saprolitizado y secuencia sedimentaria suprayacente en San Manuel, Lobería, Sierras Septentrionales de Buenos Aires, Argentina: 7 Reunión de Sedimentología, Salta, Argentina, Actas, p. 143-153.

ZALBA, P.E., AND ANDREIS, R.R., 2001, Stratigraphy, sedimentology and mineralogy of Neoproterozoic and early Paleozoic clay deposits, Sierras de Tandilia, Province of Buenos Aires: Field Excursion, Guide Book, 12th International Clay Conference: a Clay Odyssey, Bahía Blanca, Argentina, 79 p.

Zalba, P.E., Andreis, R.R., And Lorenzo, F., 1982, Consideraciones estratigráficas y paleoambientales de la Secuencia Basal Eopaleozoica en la Cuchilla de Las Águilas, Barker, Argentina: 5 Congreso Latinoamericano de Geología Argentina, Buenos Aires, Actas, 2, p. 389-409.

Zalba, P.E., Andreis, R.R., And IÑíguez, A.M., 1988, Formación Las Águilas, Sierras Septentrionales de Buenos Aires, nueva propuesta estratigráfica: Asociación Geológica Argentina, Revista, v. 43, p. 198-209.

Zalba, P.E., IÑíguez, A.M., Volzone, C., And Morosi, M.E., 1996, Mineralogía y procesos postdeposicionales en la sucesión superior de la Formación Cerro Largo, Sierras Bayas, (Buenos Aires) Argentina: 6 Reunión Argentina de Sedimentología, Bahía Blanca, Actas, p. 299-304.

Zalba, P.E., Manassero, M., Morosi, M.E., and Segovia, L., 2004, Deslizamientos diferenciales y diques clásticos en la Formación Loma Negra (Neoproterozoico) Olavarría, Sierras Septentrionales de Buenos Aires: 10 Reunión Argentina de Sedimentología, San Luis, Resúmenes, p. 178-180.

Received 25 July 2005; accepted 8 December 2006. 